\title{
On the Labor Theory of Property: Is The Problem Distribution or Predistribution?
}

\author{
David Ellerman \\ University of California/Riverside \\ www.ellerman.org
}

\section{Introduction}

Much of the recent discussion in progressive circles [e.g., Stiglitz 2012; Galbraith 2012; Piketty 2014] has focused the obscene mal-distribution of wealth and income as if that was "the" problem in our economic system. And the proposed redistributive reforms (e.g., changes in income, wealth, and estate taxes, increased minimum wages, income caps, and universal basic incomes) have all stuck to that framing of the question.

To put the question in historical perspective, one might note that there was a similar, if not more extreme, mal-distribution of wealth, income, and political power in the Antebellum system of slavery. Yet, it should be obvious to modern eyes that redistributions in favor of the slaves (surely a good thing), while leaving the institution of owning workers intact, would not address the root of the problem.

The system of slavery was eventually abolished in favor of the system we have today which differs in two important respects: (1) the workers are only rented, ${ }^{1}$ hired, or employed (i.e., the employer/master only buys some, but not all, of employee's labor); and (2) the rental relationship between employer and employee is voluntary.

Today, the root of the problem is the whole institution for the voluntary renting of human beings, the employment system itself, not the terms of the contract or the accumulated consequences in the form of the mal-distribution of income and wealth.

\section{The classical-liberal-neoclassical framing of the labor question}

What is the orthodox defense of the institution of voluntarily renting human beings? It has several layers. The first layer of defense is that the employment contract is voluntary, and, indeed, it $i s$ voluntary by any normal juridical standards. ${ }^{2}$ That defense is supposed to remove the employment relation out of the category of possibly being per se invalid — so any remaining questions can only be about the terms. 
Here again, it may be helpful to repose the question about the prior system of owning all of a worker's labor. What if that system was based on a voluntary contract? Conventional intellectual history has long displayed a studied ignorance of the fact that the sophisticated arguments for that peculiar institution were indeed based on seeing the incidence of contract from Roman Law down to Antebellum America. The real argument for the abolition of the voluntary purchase of all a worker's labor was the theory of inalienable rights that descends from the Reformation (i.e., inalienability of conscience) and Enlightenment (principally, Spinoza and Hutcheson) down to the present in the Abolitionist Movement [Ellerman 1992, 2010]. The "problem" in the historical remembrance of that inalienable rights critique of the voluntary contract to sell all of one's labor at once (the factual inalienability of human agency) is that it clearly also applies to the current system of piecemeal selling of labor-so that critique must go down the memory hole of intellectual history.

Let's move to the second layer of defense of the renting of human beings, the question of the terms of the voluntary contract. One old critique was Marx's labor theory of value and exploitation which argued that the worker's labor "is paid below its value".

It will be seen later that the labour expended during the so-called normal day is paid below its value, so that the overtime is simply a capitalist trick to extort more surplus labour. In any case, this would remain true of overtime even if the labourpower expended during the normal working day were paid for at its full value. [Marx 1977, fn. p. 357]

But, outside the dwindling band of the faithful, Marx's labor theory of value and exploitation has long been discredited (and correctly so) - in addition to being superficial since it was not a critique of the institution of wage labor per se, but only a critique of labor being "paid below its value". ${ }^{3}$

It takes a theory to kill a theory, so the real response of the defenders of the employment system was not just criticism of the labor theory of value but the marginalist revolution with the marginal productivity theory of distribution as part of the ideal competitive model.

Today it is amazing how many heterodox critics of the system frame their "criticism" in terms of how the actual system falls short of competitive ideal - as if neoclassical theory had intended the competitive model as being descriptive. Frank Knight was arguably the most able and forthright defender of the system and he was quite clear on the role of the competitive ideal. 
Economic theory is not a descriptive, or an explanatory, science of reality. Within wide limits, it can be said that historical changes do not affect economic theory at all. It deals with ideal concepts which are probably as universal for rational thought as those of ordinary geometry. [Knight 1969, p. 277]

The competitive model is not intended to be descriptive; it is postulated as the ideal around which to frame and limit the normative discussion, e.g., are workers paid the value of their marginal product as in the competitive model? Even the most slavish neoclassical (or Austrian) defender of the faith is well aware that human rental markets are not perfectly competitive. Yet most progressive and heterodox critics of marginal productivity theory, e.g., Lester Thurow [1975], John Rawls [1971], and Steve Keen [Chapter 6, 2011] in addition to Stiglitz and Piketty, do not mount any criticism of the distributive ideal of marginal productivity but only focus on issues such as the non-competitiveness and other "imperfections" of labor markets, measurement difficulties, and the background mal-distribution of wealth — all of which were long ago acknowledged by sophisticated defenders of the system of human rentals such as Knight.

Indeed, how can one criticize the ideal of paying rented human beings the value of their marginal product? Isn't that the very ideal of "reaping what you sow"? As Knight argued, the competitive system satisfies:

justice by the principle of equality in relations of reciprocity, giving each the product contributed to the total by its own performance ("what a man soweth that shall he also reap"). [Knight 1956, p. 292]

Otherwise, as John Bates Clark pointed out:

A plan of living that should force men to leave in their employer's hands anything that by right of creation is theirs, would be an institutional robbery - a legally established violation of the principle on which property is supposed to rest. [Clark 1899, pp. 8-9]

\section{Developing "the labor theory": the fork in the road}

In order to criticize the distributive ideal of paying labor according to marginal productivity, one must go outside the usual orbit of concepts covered in neoclassical, Austrian, or even most heterodox economics. Indeed, we have to go back to the first half of the $19^{\text {th }}$ century, and take the other fork in the road [Ellerman 2016]. 


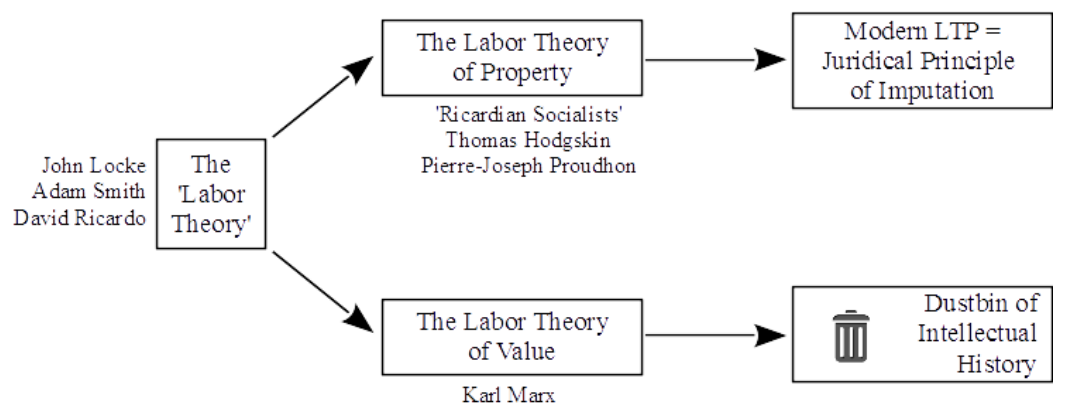

The Fork in the Road: How to Develop the "Labor Theory"

There was a small band of heterodox political economists, including Thomas Hodgskin [1832], Pierre-Joseph Proudhon [1840], and the so-called "Ricardian socialists" (although they were neither) who tried to develop the inchoate in-the-air "labor theory" into a labor theory of property [Menger, 1899] rather than a labor theory of value. In the history of economic ideas, these early attempts to develop a labor theory of property were largely overshadowed by Karl Marx's monumental attempt to develop a labor theory of value — whose eventual failure has made it the favorite foil of orthodox economics.

It might be noted that the critique of the labor theory of value has become such a part of the DNA of neoclassical/Austrian economics that it cannot even "hear" about the labor theory of property without automatically assuming one is talking about the labor theory of value. "Oh, you are really saying that only labor produces value, and thus all value should go to labor-so let me tell you why that value theory is completely discredited." Hence no neoclassical/Austrian text, to the author's knowledge, even discusses the modern treatment of the labor theory of propertywhich has nothing to do with value or price theory (e.g., no prices are used in this article).

\section{The Neglect of the Question of Appropriation}

One cannot see the answer to the question (of appropriation) if one has not even formulated the question. The labor theory of property is a normative theory that applies to the creation and termination of property rights (i.e., appropriation) in normal production (and consumption) activities. But there is also a descriptive theory of property as to how property rights are created and terminated in a private property market economy. The flows of property rights should always be described in an algebraically symmetric manner reflecting both assets and liabilities. In a common stylized picture of production, the input services, say K and L, are used up and the 
outputs Q are produced. The assets Q are created so one property-theoretic question is: "Who is to own those assets?" The services K and L (including intermediate goods) are used up so another property-theoretic question is: "Who is to owe those liabilities?" 4 The two questions together are: "Who is to legally appropriate the assets and liabilities $(\mathrm{Q},-\mathrm{K},-\mathrm{L})$ created in a productive opportunity?"

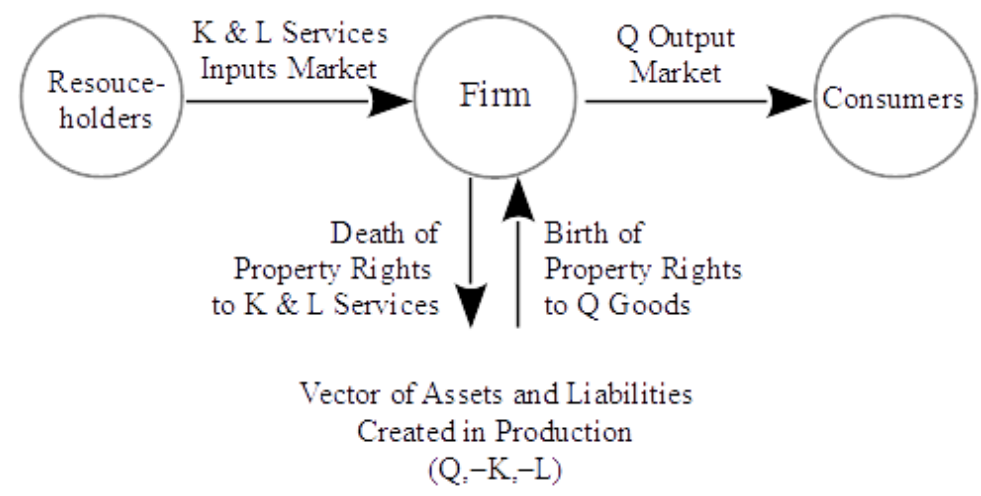

Assets and liabilities created in production

It is a remarkable fact — which itself calls for explanation - that economic theory does not even formulate the question about the initiation and termination of property rights in these normal activities of production.

One reason for the neglect is that discussions of property tend to be restricted to a mythical state of nature [e.g., Locke 1690] or to the appropriation of unclaimed or commonly owned natural goods [e.g., Cooter and Ulen 2004] rather than the everyday matters of production where property rights are constantly created and terminated. On the liability side, the law and economics literature looks extensively at the assignment of liabilities in the legal trials that may follow the accidental destruction of property [Calabresi 1970]. But what is the mechanism for assigning the liabilities for the normal deliberate using-up of inputs in production?

\section{The Fundamental Myth about property rights}

The most basic reason why the question of appropriation in production apparently cannot be raised is the "Fundamental Myth" that is largely swallowed whole by both the Left and Right. The Fundamental Myth is the idea that the rights to the product (and, incidentally, the management rights over production) are part and parcel of "the ownership of the means of production" (to use the Marxian phrase). There is no need to raise the question of who should own the assets (and 
owe the liabilities) created in production since it is all supposedly part of the already-existing ownership of "capital."

The idea goes back to the medieval notion of "dominion" or ownership of land as including the governance rights over the people living on and working the land as well as to the fruits of their labor. One of Marx's most basic blunders was to carry over this idea substituting capital for land.

It is not because he is a leader of industry that a man is a capitalist; on the contrary, he is a leader of industry because he is a capitalist. The leadership of industry is an attribute of capital, just as in feudal times the functions of general and judge were attributes of landed property. [Marx 1977, pp. 450-451]

It is conceptually trivial to see that in the current market system, the product and governance rights are not attached to the ownership of capital - consider the case where the capital is rented out. The party who hired in the capital and paid for all the other used-up inputs would have the legally defensible first claim on the produced output, not the owner of the capital asset.

The Fundamental Myth usually hides behind misconceptions such as the question: "Are you saying a corporation's ownership of its product is a myth?" Of course, a corporation owns "its product" (by definition of "its") but what determines whether or not the product produced using, say, its factory building is "its product"? For instance, must the Studebaker Corporation own the cars that rolled off the assembly line in the factory owned by Studebaker? Since Studebaker at one point leased one of its plants to another automaker, the answer is actually "No." Those cars were owned by the other company who was making the lease payments and paying for all the other inputs in car production and who thus would have the defensible claim on the produced cars.

The legal party who ends up appropriating (i.e., having the defensible claim on) the produced assets is the party, sometimes called the "residual claimant," who was the contractual nexus of hiring (or already owning) all the inputs used up in production (and thus who "swallowed" those liabilities). Since that party is determined by who hires what or whom (and power relations in the market certainly affects that outcome), the property rights to the product are not part of some prior bundle of rights to a capital asset or to a corporation. If competition arises so that the suppliers or customers of a going-concern business go elsewhere, then the so-called "owner of the firm" 
cannot claim that any actual (as opposed to mythical) property rights have been violated. Market economists should at least be able to understand that.

The grip of the Fundamental Myth in one form or another seems to account for the failure to even formulate the question of the appropriation of the assets and liabilities that are created in normal production activities. The defenders of the human rental system are only too happy to accept Marx's Gift, the fundamental-myth characterization of the system as being based on the "private ownership of capital" and thus also the misnomer of "capitalism." Marx's Gift thus allows the defenders of the "institutional robbery" of the human rental system (i.e., Proudhon's "property is theft" system) to pose as the "defenders" of private property rights.

Knight was quite clear on "capitalism" being a misnomer and that the employer may not be the owner of the capital.

Karl Marx, who in so many respects is more classical than the classicals themselves, had abundant historical justification for calling, i.e., miscalling - the modern economic order "capitalism." Ricardo and his followers certainly thought of the system as centering around the employment and control of labor by the capitalist. In theory, this is of course diametrically wrong. The entrepreneur employs and directs both labor and capital (the latter including land), and laborer and capitalist play the same passive role, over against the active one of the entrepreneur. It is true that entrepreneurship is not completely separable from the function of the capitalist, but neither is it completely separable from that of labor. The superficial observer is typically confused by the ambiguity of the concept of ownership. [Knight, 1956, p. 68, fn. 40]

The "confused" myth about the "ownership" of the means of production is not part of the actual legal system where capital goods are just as rentable as people. But it $i$ part of neoclassical capital theory and corporate finance theory [Ellerman 1992] and is apparently accepted or perhaps not even noticed by the heterodox Cambridge critics of capital theory [Harcourt 1972] who only criticize orthodox capital theory because of aggregate notions of capital, reswitching, and all that.

So far our task has just been to clear away the ideological dreck (largely shared by the Right and Left) so that the descriptive and normative question of appropriation in production can be clearly formulated.

If we use the highly stylized description of a productive opportunity given by a production function $Q=f(K, L)$, then the list or "vector" of assets and liabilities created in productive opportunity is $(\mathrm{Q},-\mathrm{K},-\mathrm{L})$. 
- The descriptive question of appropriation is: "How is it that one legal party rather than another ends up legally appropriating $(\mathrm{Q},-\mathrm{K},-\mathrm{L})$ ?"

- The normative question of appropriation is: "What legal party ought to legally appropriate $(\mathrm{Q},-\mathrm{K},-\mathrm{L})$ ?"

\section{The descriptive question of appropriation}

The descriptive question is easily answered from our previous discussion. There is a laissezfaire or market mechanism for the assignment of the liabilities and assets created production in a private property market economy. One legal party purchases (or already owns) all the inputs necessary for a productive opportunity and instead of reselling those inputs, that party shoulders, swallows, or absorbs those liabilities when the inputs are consumed in production. Then having borne all the costs involved in the productive opportunity, that same legal party has the legally defensible claim on the produced outputs which are typically sold. Thus in terms of property rights and liabilities, one legal party appropriates $100 \%$ of the input-liabilities $(0,-\mathrm{K},-\mathrm{L})$ as well as $100 \%$ of the output-assets $(\mathrm{Q}, 0,0)$. In property terms, there are no "distributive shares"; that is only a value-theoretic metaphor.

The $100 \%$ appropriation of the input-liabilities and output-assets by one legal party is a simple legal fact. Yet the economics profession is so imbued with the distributive shares picture that one will search in vain through the modern texts to find that simple legal fact mentioned. One has to go back to economics texts prior to the marginalist revolution to find such a simple statement about the actual property rights.

Being equally, however, the owner of the labour, so purchased, as the owner of the slave is of that of the slave, the produce, which is the result of this labour, combined with his capital, is all equally his own. In the state of society, in which we at present exist, it is in these circumstances that almost all production is effected: the capitalist is the owner of both instruments of production: and the whole of the produce is his. [Mill, James 1826, Chapter I, section II]

\section{The normative question of appropriation}

First a matter of terminology. The list of input-liabilities and output-assets $(\mathrm{Q},-\mathrm{K},-\mathrm{L})$, that is called the "production vector" or "input-output vector" in modern neoclassical texts, can be identified with the notion of the whole product [which is composed of the negative product 
$(0,-\mathrm{K},-\mathrm{L})$ plus the positive product $(\mathrm{Q}, 0,0)]$ that was used in the old slogan of "Labour's claim to the whole product" highlighted by Carl Menger's jurisprudentially-trained brother, Anton [Menger 1899]. It is true that this tradition put the emphasis on the positive product but since they could hardly expect some other party to pay their production costs, we will interpret their notion of whole product in modern terms as including the negative product, the input-liabilities.

Thus the normative question of appropriation is: "Who ought to appropriate the whole product in any given productive opportunity?" That party, the whole product appropriator, is rightly labeled the "firm" (in the going-concern sense of being the firm instead of "owning" the firm). Hence we have the prior Question of Predistribution: "Who ought to be the firm-in the first place?" as opposed to the usual Question of Distribution: "What should be the firm's distributive shares?" The traditional answers to the Question of Predistribution are: Capital (the owners of the "means of production"), Labor (the legal party consisting of all who work in the enterprise), the State (as in present or past Marxian socialism), or perhaps just any entrepreneurial party who employs all the necessary inputs, bears those costs, and then claims and sells the outputs.

\section{The juridical principle of imputation}

The other fork in the "labor-theory" road is the largely untraveled labor theory of property that answered the normative Question of Predistribution with "Labor's right to the whole product." The key insight in the modern treatment of that old theory is that it is simply the property-theoretic application of the usual juridical principle of imputation: assign legal responsibility in accordance with factual responsibility. The principle is so basic and obvious that it is usually not even stated explicitly. For instance, in a jury trial, the jury is charged with making the official decision about whether or not the defendant is factually responsible as charged — and then the legal system, without further question, assigns or imputes the legal responsibility accordingly. The imputation principle applies in the first instance to deliberate human actions (not the accidents focused on in the law and economics literature), and the most deliberate of all human activities is production where the deliberate human actions are called "labor" (in the broad sense of all who work in an enterprise). That is why the old labor theory of property is, in modern terms, just the property-theoretic application of the juridical imputation principle. 
In factual terms, all who work in a productive opportunity (regardless of their legal role of employer or employee) are jointly de facto responsible for using-up the inputs and thus, by the imputation principle, they should be the legal party who owes those legal liabilities. And by those same deliberate human actions, they produce the outputs and thus, by the same imputation principle, they should legally own those assets. Thus the application of the standard principle of imputation to production provides the juridical basis for the old claim of "Labor's right to the whole product" - to the positive and negative fruits of their joint labor.

But what about the employment contract? The employees voluntarily sold their labor services to the employer. Here the analysis makes contact with the aforementioned theory of inalienable rights that provided the basis for the abolition of a voluntary contract for selling labor by the lifetime. In a contract to sell or rent out a material instrument such as a wrench or a truck, the owner of the instrument can factually fulfill the contract by turning over the use of the instrument to the buyer or renter so that party can be factually responsible for using it and for whatever is thereby produced. The services of a thing are factually alienable.

But the same transfer to fulfill the contract is not factually possible when a person voluntarily sells or rents out themselves. Responsible human agency is factually inalienable. ${ }^{6}$ At most, a person can and typically does voluntarily agree to follow the instructions of the employer, but then, in factual terms, they each share some of the responsibility for the results of their joint actions. But if no crime has been committed, then the legal authorities do not intervene to assign legal responsibility in accordance with that joint factual responsibility. Instead the legal system just counts "obeying the employer" as "fulfilling" the labor contract—even though there has been no factual transfer of responsible human actions ("labor services") unlike the case of the factual transfer of the services of things like a wrench or truck. And then as we saw in the description of the market mechanism of appropriation, one legal party (the employer) paid for all the input services (e.g., the services of the rented wrenches, trucks, and persons) so that party absorbs those liabilities and thus has the defensible legal claim on the produced outputs. Thus the employment system inherently violates the juridical principle of imputation since one party is factually responsible for the whole product (the party consisting of all who work in the enterprise) while another party legally appropriates the whole product (the legal party playing the role of the employer). The employees in an employment firm have zero legal claims against them (qua 
employees) for the input-liabilities (they are only one of the parties to whom the wage-liability is owed) and they have zero legal claims (qua employees) on the output-assets - which is exactly the legal role of a rented thing. As usual, Frank Knight expresses it best:

It is characteristic of the enterprise organization that labor is directed by its employer, not its owner, in a way analogous to material equipment. Certainly there is in this respect no sharp difference between a free laborer and a horse, not to mention a slave, who would, of course, be property. [Knight 1965, p. 126]

This can be illustrated using our "priceless" example. All who work in a production opportunity ("Labor" including managers) are de facto responsible for using up the inputs $\mathrm{K}$ to produce the outputs $\mathrm{Q}$, which is summarized as Labor's product $(\mathrm{Q},-\mathrm{K}, 0)$ ). But Labor (qua Labor) only legally appropriates and sells $(0,0, \mathrm{~L})$ in the employment system. Labor is de facto responsible for but does not appropriate the difference which is the "institutional robbery" of the whole product:

$$
(\mathrm{Q},-\mathrm{K}, 0)-(0,0, \mathrm{~L})=(\mathrm{Q},-\mathrm{K},-\mathrm{L})
$$

Table 1

\begin{tabular}{|l|l|l|}
\hline Labor de facto responsible for & $(\mathrm{Q},-\mathrm{K}, 0)$ & = Labor's product \\
\hline Labor legally appropriates & $(0,0, \mathrm{~L})$ & = labor commodity \\
\hline $\begin{array}{l}\text { Labor de facto responsible for } \\
\text { but does not appropriate }\end{array}$ & $\begin{array}{l}(\mathrm{Q},-\mathrm{K}, 0) \\
=(\mathrm{Q}, 0, \mathrm{~L})\end{array}$ & = whole product. \\
\end{tabular}

Imputation Principle Violation under the Employment System

It is easy to see why neoclassical economists are so addicted to the picture of the employees as metaphorical "partners" getting their distributive share of the product! They ask: "Can't we just ignore the actual assignation or imputation of property rights and liabilities in an employment firm and focus our attention on the size of labor's share of the product — which is justified in the ideal competitive case by the wonderful theory of marginal productivity?"

Before turning to marginal productivity theory, we might consider the legal system's acceptance of the employee's inextricably co-responsible performance as "fulfilling" the contract for the transfer of labor - when a crime in committed at the behest of the employer. The servants in work suddenly become the partners in crime.

All who participate in a crime with a guilty intent are liable to punishment. A master and servant who so participate in a crime are liable criminally, not because 
they are master and servant, but because they jointly carried out a criminal venture and are both criminous. [Batt 1967, p. 612]

When the venture being "jointly carried out" is non-criminous, the workers do not suddenly become non-persons or instruments being "employed" by the "employer." The facts about de facto responsible co-operation remain the same. ${ }^{7}$ It is the reaction of the legal system that changes when no legal wrong is recognized. Then legal authorities accept the employees' coresponsible cooperation as "fulfilling" the human rental contract so there is no need for a legal intervention to make the imputation in accordance with the actual de facto responsibility. The input-suppliers have supplied their inputs fulfilling their side of the input contracts and employer has paid all the costs (and thus appropriates the input-liabilities) fulfilling his side of the input contracts, and thus the employer also has the defensible legal claim on the produced output.

In this manner, the employer legally appropriates the whole product — which is the negative and positive fruits of the de facto responsible human actions of all who work in the enterprise. That is the "institutional robbery - a legally established violation of the principle on which property is supposed to rest" [Clark 1899, p. 9] at the core of our private property market economy. Far from implying the abolition of private property, we may paraphrase Gandhi and say: "It would be a good idea to have a real private property market economy based on the principle of people legally appropriating the positive and negative fruits of their labor-instead of the property-as-theft system we have now based on the fraudulent and inherently invalid contract for the renting of human beings." That would imply the abolition of the contract to rent, hire, or employ human beings in favor of companies being reconstituted as democratic organizations whose members are the people working in the enterprise [Ellerman 1990].

But orthodox economists will respond:

Please, we're economists; we can't talk about property rights and contracts or some so-called "juridical principle of imputation." That's not even part of Economics! So let's talk about prices. What you probably mean to say is that workers produce more value than they are paid - and we largely agree with you since markets are far short of the competitive ideal as is correctly pointed out by progressive economists such as Stiglitz, Piketty, Thurow, and Keen as well as by philosophers such as Rawls. But in the ideal competitive case, workers are paid the value of their marginal product so workers "reap what they sow." Hence let's talk about making markets more competitive so workers will really be paid the value of their marginal product, and then your concerns about justice - which we share-will be satisfied. 
Hence we turn to marginal productivity theory.

\section{Marginal Productivity Theory}

Actually neoclassical economists are already quite familiar with a certain version of the juridical imputation principle since it is routinely applied (or implied) in the interpretation of marginal productivity (MP) theory in competitive markets. ${ }^{8}$ However, this attempted application of the imputation principle is based on:

- a metaphor,

- a mistake, and

- a miracle.

\section{The Metaphor: Treating Services of Things like the Actions of Persons}

The first and foremost problem is the neglect of the difference between responsible human actions and the non-responsible but causally efficacious (i.e., productive) services of things like a wrench or truck. All are treated simply as causally effective productive services. As usual, Knight expresses it best.

We have insisted that the word "produce" in the sense of the specific [i.e., marginal] productivity theory of distribution, is used in precisely the same way as the word "cause" in scientific discourse in general. [Knight 1965, p. 178]

For "labor" we should now say "productive resources." [Knight 1956, p. 8]

There is an old literary metaphor (a version of the pathetic fallacy) where natural forces are pictured in an animistic way as being "responsible" for certain consequences. Economists sometimes indulge these picturesque images as when an asset is imagined as producing a (marginal) product or when natural forces and human actions are coupled together as if both were de facto responsible.

Goods are typically produced by the co-operation of various kinds of productive services, and the special problem of distribution, in modern terms, is that of the division of this joint product among the different kinds of co-operating productive services and agents. [Knight 1956, p. 21]

"Together, the man and shovel can dig my cellar" and "land and labor together produce the corn harvest" [Samuelson 1976, pp. 536-537]. However, since the demise of primitive animism, the law has only recognized persons as being responsible agents. When orthodox economists are on 
jury duty for a murder trial, they will probably drop their learned ignorance of difference between the responsible actions of person and the causally efficacious services of things. They would probably not wonder — or, at least, not out loud—how to effect the "division" of the joint responsibility "among the different kinds of co-operating productive services and agents." They might even understand that the responsibility for the murder is imputed back through any gun or other weapon to the person using those instruments.

As the legally-trained Austrian economist, Friedrich von Wieser, put it:

The judge ... who, in his narrowly-defined task, is only concerned with the legal imputation, confines himself to the discovery of the legally responsible factor, that person, in fact, who is threatened with the legal punishment. On him will rightly be laid the whole burden of the consequences, although he could never by himself alone-without instruments and all the other conditions-have committed the crime. The imputation takes for granted physical causality....

If it is the moral imputation that is in question, then certainly no one but the labourer could be named. Land and capital have no merit that they bring forth fruit; they are dead tools in the hand of man; and the man is responsible for the use he makes of them. [Wieser 1889, pp. 76-79]

For instance, a description without the animistic metaphor would be that a man is responsible both for using up the services of a shovel and for thereby digging a cellar (note the positive and negative side of responsibility) — or that labor uses up the services of land in the production of the corn harvest.

There is a common pose that orthodox economists are judging the existing system according to some normative principles, but the causality seems to be the reverse. Normative principles are judged according to whether or not they align with the social role of orthodox economics in giving a "scientific account" of the existing human rental system. For instance, Wieser summarizes the essence of the labor theory of property (juridical imputation principle) critique of the employment system-"Land and capital have no merit that they bring forth fruit; they are dead tools in the hand of man; and the man is responsible for the use he makes of them." But that gives Wieser no second thoughts about the system of renting human beings; it only shows that the usual moral or legal notions of imputation obviously do not apply! The social role of economics in the human rental system requires a new notion of "economic imputation" in accordance with another new notion of "economic responsibility". 
In the division of the return from production, we have to deal similarly ... with an imputation, - save that it is from the economic, not the judicial point of view. [Wieser 1889, p. 76]

By defining "economic responsibility" in terms of the animistic version of marginal productivity, Wieser and later orthodox economists can finally draw the conclusion demanded by their calling: to show that the competitive employment system "economically" imputes the product in accordance with "economic" responsibility. Thus we arrive at one of the highpoints of neoclassical microeconomics: trying to justify a metaphorical imputation of the product with a metaphorical notion of "responsibility."

\section{The Mistake: No Division of the Product in terms of Property Rights}

The simple mistake involved in this interpretation of MP theory is that it does not deal with the Question of Predistribution: "Who is to be the whole product appropriator - in the first place?"9 In an enterprise, one legal party, typically the employer, legally appropriates the:

$$
(\mathrm{Q},-\mathrm{K},-\mathrm{L})=(\mathrm{Q}, 0,0)+(0,-\mathrm{K},-\mathrm{L}) .
$$

Whole product $=$ Positive product + Negative product

There is no division of the property rights to the product. In order to address that question about the actual appropriation of the assets and liabilities created in production, one needs a theory of property, whereas marginal productivity theory is actually only a theory of the derived demand for inputs.

\section{The Miracle: Each Factor's Immaculate Production of its Marginal Product}

The whole picture of each unit of a factor producing its marginal product is not even remotely plausible in the first place since production requires other inputs! Each (marginal) unit of the labor L cannot "immaculately" produce ex nihilo its marginal product $\mathrm{MP}_{\mathrm{L}}=\Delta \mathrm{Q} / \Delta \mathrm{L}$ of somany widgets without using up some services of capital (and other intermediate goods summarized in $\mathrm{K}$ ).

Given an increase in labor of $\Delta \mathrm{L}$, the usual computation of the marginal product of labor $\Delta \mathrm{Q} / \Delta \mathrm{L}$ involves a shift to a slightly more labor-intensive production process so that $\Delta \mathrm{Q}$ extra product is produced with no change in the other factors, i.e., $\Delta \mathrm{K}=0$. But that shift in general would violate the cost-minimization assumption that requires expansion along the least-cost 
expansion path. Thus the $\Delta \mathrm{L}$ would typically require an increase in the other inputs $\mathrm{K}$ in order to produce some extra output $\Delta \mathrm{Q}$ at minimum costs. Hence in place of the usual scalar notion of $\mathrm{MP}_{\mathrm{L}}$, the neoclassical assumptions require a vector notion of marginal product to account for those changes in the other inputs necessary to stay on the least-cost expansion path. Hence the vector marginal product of the extra labor $\Delta \mathrm{L}$ would be a vector $\mathbf{M P}_{\mathbf{L}}=(\Delta \mathrm{Q},-\Delta \mathrm{K}, 0)$. And since labor is the only de facto responsible factor, the total labor L would be de facto responsible for the sum (or integral in technical terms) of the vectorial marginal products of labor from 0 to $\mathrm{L}$ which is exactly what we previous termed: ${ }^{10}$

$$
\text { Labor's product }=(\mathrm{Q},-\mathrm{K}, 0) \text {. }
$$

Of course, the same mathematical calculations can be made for the causally efficacious but nonresponsible inputs $\mathrm{K}$ (e.g., capital), but since non-responsible things do not qualify for imputation, that calculation has no normative significance.

Thus redoing the MP theory taking account of the non-metaphorical fact that in terms of legal or moral imputation "no one but the labourer could be named," we are taken right back to the labor theory of property as the property-theoretic application of the juridical principle of imputation.

This raises the question of why doesn't neoclassical economics follow out its own assumptions by using the vector marginal products taken along the least-cost expansion path instead of the notional (immaculate) marginal products off that path? The answer seems to be that only the immaculate marginal products gives the "distribution of the product" or "distributive shares" picture (with the "exhaustion of the product" under constant returns to scale)—which can then be combined with the pseudo-application of the imputation principle to show that the competitive employment system satisfies "the ethical proposition that an individual deserves what is produced by the resources he owns." [Friedman 1976, p. 199]

\section{Workplace Democracy: The Alternative to the Employment System}

If the neo-abolitionist proposal were accepted that the contract for the renting of human beings be recognized as invalid and be abolished, then production could only be organized on the basis of the people working in production (jointly) hiring or already owning the capital and other inputs they use in production. The market mechanism of appropriation would then correctly 
impute the legal responsibility to the de facto responsible party [Ellerman 2014]. The conservative thinker, Lord Eustace Percy, singled out that de facto responsible party in 1944:

Here is the most urgent challenge to political invention ever offered to the jurist and the statesman. The human association which in fact produces and distributes wealth, the association of workmen, managers, technicians and directors, is not an association recognised by the law. The association which the law does recognisethe association of shareholders, creditors and directors - is incapable of production and is not expected by the law to perform these functions. We have to give law to the real association, and to withdraw meaningless privilege from the imaginary one. [Percy 1944, p. 38]

The members of the "human association" as a legal party would then be the people working in the firm. After abolishing both the owning and the renting of persons, private property would finally be founded on "the principle on which property is supposed to rest." Such a firm is a democratic firm and the private property market economy of such firms is an economic democracy. ${ }^{11}$

\section{For Further Reading}

Batt, Francis. 1967. The Law of Master and Servant. 5th ed. London: Pitman.

Black, Henry 1968. Black's Law Dictionary. St. Paul: West Publishing.

Calabresi, Guido 1970. The Costs of Accidents: A Legal and Economic Analysis. New Haven: Yale University Press.

Clark, John Bates. 1899. The Distribution of Wealth. New York: Macmillan.

Cooter, Robert, and Thomas Ulen. 2004. Law and Economics (4th Ed.). Boston: Pearson Addison-Wesley.

Dahl, Robert. 1985. Preface to Economic Democracy. Berkeley: University of California Press.

Ellerman, David. 1990. The Democratic Worker-Owned Firm. Boston: Unwin-Hyman. Reprinted by Routledge Revivals, 2015. All my cited works available at: www.ellerman.org.

Ellerman, David. 1992. Property \& Contract in Economics: The Case for Economic Democracy. Cambridge MA: Blackwell.

Ellerman, David. 1995. Intellectual Trespassing as a Way of Life: Essays in Philosophy, Economics, and Mathematics. Lanham MD: Rowman \& Littlefield.

Ellerman, David. 2010. Inalienable Rights: A Litmus Test for Liberal Theories of Justice. Law and Philosophy 29 (5 September): 571-99.

Ellerman, David. 2014. On Property Theory. Journal of Economic Issues XLVIII (3 (Sept.)): 601-24. 
Ellerman, David. 2016. The Labour Theory of Property and Marginal Productivity Theory. Economic Thought 5 (1): 19-36.

Friedman, Milton. 1962. Capitalism and Freedom. Chicago: University of Chicago Press.

Friedman, Milton 1976. Price Theory. Chicago: Aldine.

Galbraith, James K. 2012. Income and Instability. New York: Oxford University Press.

Harcourt, G. C. 1972. Some Cambridge Controversies in the Theory of Capital. Cambridge UK: Cambridge University Press.

Hodgskin, Thomas. 1832. The Natural and Artificial Right of Property Contrasted. Clifton NJ: Augustus M. Kelley (1973).

Keen, Steve. 2011. Debunking Economics—Revised and Expanded Edition: The Naked Emperor Dethroned? London: Zed Books.

Knight, Frank H. 1956. On the History and Method of Economics. Chicago: Phoenix Books.

Knight, Frank H. 1965. Risk, Uncertainty and Profit. New York: Harper Torchbooks.

Knight, Frank H. 1969. The Ethics of Competition and Other Essays. Freeport NY: Books for Libraries Press.

Locke, John. 1690. Two Treatises of Government. New York: New American Library (1960).

Marx, Karl. 1977. Capital (Volume I). Trans. by B. Fowkes. New York: Vintage Books.

Menger, Anton. 1899. The Right to the Whole Produce of Labour: The Origin and Development of the Theory of Labour's Claim to the Whole Product of Industry. Trans. M. E. Tanner.

London: Macmillan and Co (Also reprinted by Augustus Kelley, 1970).

Mill, James. 1826. Elements of Political Economy. 3rd ed. London.

Oakeshott, Robert. 1978. The Case for Workers' Co-ops. London: Routledge and Kegan Paul.

Percy, Eustace. 1944. The Unknown State: 16th Riddell Memorial Lectures. London: Oxford University Press.

Piketty, Thomas. 2014. Capital in the Twenty-First Century. Trans. Arthur Goldhammer. Cambridge MA: Harvard University Press.

Proudhon, Pierre-Joseph. 1840. What is Property? New York: Dover (1970).

Rawls, John. 1971. A Theory of Justice. Cambridge: Harvard University Press.

Samuelson, Paul A. 1976. Economics (10 ${ }^{\text {th }}$ ed.). New York: McGraw-Hill.

Stiglitz, Joseph. 2012. The Price of Inequality: How Today's Divided Society Endangers Our Future. New York: W.W. Norton.

Thurow, Lester. 1975. Generating Inequality: Mechanisms of Distribution in the U.S. Economy. New York: Basic Books.

Whyte, William F. and Kathleen K. Whyte. 1991. Making Mondragon. Ithaca: ILR Press.

Wieser, Friedrich von. 1889. Natural Value. trans. C.A. Malloch, New York: G.E. Stechert and Company (1930). 


\section{Wigforss, Ernst. 1923. Den Industriella Demokratiens Problem 1. Stockholm: A.-B. Hasse W. Tullbergs boktryckeri.}

${ }^{1}$ The word "rented" is used deliberately even though American English prefers to say that cars are rented but people are hired. In the UK, rental cars are called "hire cars" and the economic relationship (buying the services of a productive factor instead of the ownership of the factor) is the same no matter what it is called. Moreover, this is not a matter of controversy; as the late dean of neoclassical economics, Paul Samuelson, put it: "Since slavery was abolished, human earning power is forbidden by law to be capitalized. A man is not even free to sell himself: he must rent himself at a wage." [Samuelson 1976, p. 52 (his italics)]

${ }^{2}$ By any standards, a collectively-bargained employment contract is "more" voluntary than the usual contract of adhesion between an individual consumer and a supermarket.

${ }^{3}$ The point is about Marx's theory that "wages are too damn low," not his personal views. Of course, he was personally against the institution of wage labor, at least in its private form. The point is that he only brought a value theory to a property-theoretic fight, so it would have still been ineffectual even if it was a good value theory.

4 The termination of rights was an original meaning of "expropriation." "This word [expropriation] primarily denotes a voluntary surrender of rights or claims; the act of divesting oneself of that which was previously claimed as one's own, or renouncing it. In this sense, it is the opposite of 'appropriation'. A meaning has been attached to the term, imported from foreign jurisprudence, which makes it synonymous with the exercise of the power of eminent domain, .... " [Black 1968, p. 692, entry under Expropriation]. Since "expropriation" now has this acquired meaning, I will treat the "expropriation (termination) of rights to the assets $+\mathrm{X}$ " as the "appropriation of the liabilities $-\mathrm{X}$."

${ }^{5}$ Thanks to Branko Milanovic for the idea of applying Jacob Hacker's phrase to worker ownership. For instance, legislation to increase worker ownership through Employee Stock Ownership Plan (ESOPs) or worker cooperatives is predistributive while raising taxes on the $1 \%$ is redistributive.

${ }^{6}$ Since Bernie Sanders recently raised the idea of Scandinavian social democracy, it might be noted that one of the founders of the Swedish version, Ernst Wigforss, actually had an analysis based of the labor contract being invalid because it bogusly pretends that labor can be factually transferred like a commodity. The remarkable passage (found and translated by Swedish film-maker Patrik Witkowsky) is in the 1923 report of the Wigforss Commission on industrial democracy. "There has not been any dearth of attempts to squeeze the labor contract entirely into the shape of an ordinary purchase-and-sale agreement. The worker sells his or her labor power and the employer pays an agreed price. What more could the worker demand, and how could he or she claim a part in the governance of the company? It has already been pointed out that the determination of the price can necessitate a consensual agreement on how the firm is managed. But, above all, from a labor perspective the invalidity of the particular contract structure lies in its blindness to the fact that the labor power that the worker sells cannot like other commodities be separated from the living worker. This means that control over labor power must include control over the worker himself or herself. Here perhaps we meet the core of the whole modern labor question, and the way the problem is treated, and the perspectives from which it is judged, are what decide the character of the solutions." [Wigforss 1923, p. 28] 
${ }^{7}$ Of course, a contract involving a crime is legally null and void. But the worker is not de facto responsible for the crime because he made an illegal contract. The employee is de facto responsible because the employee, together with the employer, committed the crime (not because of the legal status of the contract).

${ }^{8}$ For instance, "To each according to what he and the instruments he owns produces." [Friedman 1962, pp. 161 2].

${ }^{9}$ Much ink has been spilt by Knight [1965] and others on the near-tautology that the party who "bears the risks" (i.e., appropriates the negative product) should also appropriate the positive product. Of course, one party appropriates the whole product (i.e., both the positive and negative products). The real question is: who is to be that one party?

${ }^{10}$ The mathematics of vectorial marginal productivity theory was worked out a couple of decades ago in Chapter 5 entitled "Are Marginal Products Created Ex Nihilo?" of Ellerman [1995].

${ }^{11}$ See, for example, Dahl [1985]. The best examples today are probably the Mondragón industrial cooperatives in the Basque region of Spain [see Oakeshott 1978; Whyte and Whyte 1991; or, in their own words, http://www.mondragon-corporation.com/eng/]. 